\title{
EFEKTIVITAS LATIHAN PROGRESSIVE MUSCLE RELAXATION MENURUNKAN RESPON STRESS PSIKO-FISIOLOGIS PADA MAHASISWA
}

\author{
Systematic Review
}

\author{
Ary Astuti ${ }^{1}$ Anggorowati ${ }^{2}$ Andrew Johan ${ }^{3}$ \\ ${ }^{1,2}$ Departemen Keperawatan FK UNDIP, Divisi Keperawatan Dewasa \\ 3 Akper Pemkab Kotawaringin Timur \\ E-mail: Ary Astuti (Email : nersary83@yahoo.com), \\ Anggorowati (Email : aangham@gmail.com)
}

\begin{abstract}
ABSTRAK
Perubahan pola aktivitas dan perubahan lingkungan belajar menjadi pemicu stress pada mahasiswa yang melibatkan reaksi psiko-fisiologis. Salah satu intervensi keperawatan yang sering digunakan di klinik untuk mereduksi dampak stress adalah Progresive Muscle Relaxation/PMR, sehingga perlu dilakukan sistematic review untuk mengetahui apakah latihan PMR lebih efektif daripada terapi relaksasi lainnya dalam mereduksi dampak stress psiko-fisiologis. Tujuan penelitian untuk mengetahui keefektifan latihan PMR daripada terapi relaksasi lainnya dalam mereduksi dampak stress psiko-fisiologis. Metode: Systematic review dilaksanakan dengan menelusuri artikel pada database psychology and behavior sciences collection, googlescholar, gen.lib.rus.ec serta sciencedirect.com dengan kata kunci yang dipilih. Penelusuran dibatasi terbitan 2004-2017 yang dapat diakses fulltext dalam format pdf dengan desain RCT dan Case Control yang dilakukan pada mahasiswa. Perlakuan berupa PMR dibandingkan dengan terapi relaksasi lainnya dalam menurunkan tingkat stress, tingkat kecemasan dan kadar cortisol. Artikel yang sesuai kemudian dianalisis menggunakan critical appraisal tool yang sesuai untuk hasil penelitian RCT maupun Case Control untuk menilai kualitas penelitian. Data-data diekstraksi dari artikel lalu dikelompokkan untuk dibahas dan disimpulkan. Hasil: Tiga dari 5 buah artikel memiliki kualitas tinggi dan yang lainnya sedang. Hasil pembahasan menunjukkan bahwa latihan PMR lebih efektif menurunkan tingkat stress, tingkat kecemasan dan kadar cortisol pada mahasiswa daripada terapi relaksasi lainnya: pernapasan diafragma, latihan autogenik, small talk grup dan yoga stretching (hatha). Latihan PMR yang paling efektif dilaksanakan selama 30 menit dalam 1 hari dan apabila diterapkan 1 hari dalam seminggu selama 4 minggu akan meningkatkan tingkat relaksasi dan meningkatkan pelepasan energi. Pengulangan sampai 5 minggu dapat meningkatkan indeks kebahagiaan dan ketenangan mental. Kesimpulan: latihan PMR lebih efektif daripada terapi relaksasi lainnya dalam mereduksi dampak stress psiko-fisiologis..
\end{abstract}

Kata Kunci : cortisol, kecemasan, mahasiswa, progressive muscle relaxation, stress 


\section{PENDAHULUAN}

Stress yang dialami mahasiswa dapat menyebabkan perubahan irama sirkadia dan keluhankeluhan fisik. Stimulus-stimulus yang berasal dari luar dan dari dalam individu berupa lingkungan perkuliahan menimbulkan reaksi-reaksi tubuh baik secara neural maupun secara kimiawi. Hal ini menstimulasi sistem saraf pusat untuk melakukan respon adaptif (meningkatkan integritas personal) atau inefektif sehingga menghambat proses adaptasi. Respon inefektif yang berkepanjangan dimanifestasikan dalam keluhan-keluhan psikofisiologis (Roys, 1991 dalam Rogers-Keller, 2009). Disisi lain 27\% mahasiswa memiliki resiko mengalami gangguan tidur dan ras Afrika-Amerika dan Asia memiliki resiko yang lebih kecil mengalami gangguan tidur dibandingkan ras Latin (Gaultney, 2010).

Salah satu intervensi keperawatan yang sering digunakan untuk mereduksi dampak stress adalah Progresive Muscle Relaxation/PMR (Friedman, 1974 dalam McCallie dkk, 2006). Metode relaksasi ini bertujuan untuk menurunkan ketegangan otot seluruh tubuh dan meningkatkan suplai oksigen. Physical exercise dan progressive muscle relaxation menimbulkan perubahan ekspresi wajah sebagai salah satu indikator ketegangan psikofisiologis (Heenan, 2014). Teknik progressive muscle relaxation direkomendasikan sebagai salah satu bekal yang harus dikuasai oleh para mahasiswa menjelang akhir studi (Boyd, 2014).

Progresive muscle relaxation memiliki efek yang sebanding dengan sleep hygiene untuk mengatasi insomnia primer (Alexandru, 2009). Terapi relaksasi progressive muscle relaxation juga dapat menurunkan kadar kortisol dan meningkatkan kadar imunoglobulin A (IgA) pada saliva (Pawlow, 2005). Bahkan latihan progressive muscle relaxation dapat menurunkan kelelahan dan meningkatkan kualitas tidur pada pasien $C a$. Mammae yang mendapatkan terapi kemoterapi (Demiralp, 2009).

Dengan banyaknya manfaat latihan progressive muscle relaxation yang dilaporkan maka Penulis merasa tertarik melakukan sistematic review untuk menggali lebih jauh apakah pada mahasiswa latihan progressive muscle relaxation lebih efektif dari terapi relaksasi lainnya untuk menurunkan dampak stress psiko-fisiologis. 


\section{METODE}

Desain yang digunakan dalam tulisan ini adalah systematic review. Tipe study Publikasi hasil penelitian yang dicari dalam systematic review ini adalah yang dilaksanakan dengan desain randomised control trial (RCT) dan case control. Systematic review ini memfokuskan pada hasil-hasil penelitian yang dilakukan pada mahasiswa secara umum. Intervensi utama yang akan ditelaah dalam systematic review ini adalah latihan progressive muscle relaxation sebagai salah satu bentuk terapi relaksasi. Adapun intervensi yang akan dijadikan pembanding adalah terapi-terapi relaksasi lainnya yang terbukti dapat mengurangi sress psiko-fisiologis. Outcome yang diukur adalah tingkat stress (persepsi), tingkat kecemasan dan kadar hormon cortisol.

Strategi pencarian literatur Systematic review ini dilaksanakan dengan melakukan penelusuran artikel publikasi pada database : psychology and behavior sciences collection, googlescholar, gen.lib.rus.ec serta sciencedirect.com dengan kata kunci Progressive Muscle Relaxation, Relaxation, Nursing student stress, Student nurses, College Student, Stress, Anxiety, Cortisol.

Artikel yang ada kesamaan dalam setiap penelusuran diambil salah satunya untuk selanjutnya dianalisis kualitasnya. Penelusuran literatur dibatasi pada terbitan 2004-2017 yang dapat diakses fulltext dalam format pdf. Hasil penelusuran literatur dan ekstraksi data dapat dilihat pada tabel 1 dibawah ini :

Tabel 1.

Hasil Penelusuran Literatur dan Ekstraksi Data

\begin{tabular}{|c|c|c|c|c|}
\hline \multirow{2}{*}{ Kriteria } & \multicolumn{3}{|c|}{ Mesin pencarian } & sciencedirect.com \\
\cline { 2 - 5 } & $\begin{array}{c}\text { psychology and behavior } \\
\text { sciences collection }\end{array}$ & goooglescholar & gen.lib.rus.ec & 27 \\
\hline $\begin{array}{c}\text { Hasil penelusuran } \\
\text { awal }\end{array}$ & 774 & 2.510 & 60 & 16 \\
\hline $\begin{array}{c}\text { Fulltext, } p d f, \\
\text { 2004-2014 }\end{array}$ & 96 & 176 & 60 & 15 \\
\hline $\begin{array}{c}\text { Eligible with inclusy } \\
\text { critheria }\end{array}$ & 8 & 15 & 6 & 2 \\
\hline Eligible to analyzed & 4 & 3 & 2 & \\
\hline RESULT & & 5 & & \\
\hline
\end{tabular}


Metode pengkajian kualitas study artikel yang sesuai kriteria lalu dianalisis menggunakan critical appraisal tool yang sesuai untuk hasil penelitian RCT maupun case control. Alat ukur yang dikembangkan oleh Critical Appraisal Skills Programme (CASP) untuk menilai kualitas penelitian Penulis akses dari www.casp-uk.net. Data-data dari hasil temuan yang sudah dianalisis kemudian diekstraksi dan disintesis untuk mencapai tujuan.

Cara ekstraksi data utama yang diambil dari jurnal yang diperoleh meliputi : peneliti dan tahun penelitian, desain penelitian, jumlah dan karakteristik sampel penelitian, intervensi utama dan intervensi pembanding dan hasil penelitian. Data-data tersebut kemudian dimasukkan dalam form ekstraksi data, serta akan ditampilkan dalam bentuk tabel 2 dibawah ini :

Sintesis data dilakukan dengan mengelompokkan data-data hasil ekstraksi yang sejenis sesuai dengan hasil yang ingin diukur. Data yang sudah terkumpul kemudian dicari persamaan dan perbedaannya lalu dibahas untuk menarik kesimpulan.

\section{HASIL}

Berdasarkan pencarian diketahui bahwa terdapat 3 artikel yang memiliki kualitas yang tinggi dan sisanya sedang. Sebanyak 3 artikel menggunakan metode latihan PMR selama 30 menit, 1 artikel selama 20 menit dan sisanya selama 15 menit. Sebanyak 3 penelitian menggunakan desain RCT dan sisanya case control. Dampak progressive muscle relaxation terhadap tingkat stress berjumlah 3 penelitian, dampak progressive muscle relaxation terhadap tingkat kecemasan berjumlah 2 penelitian dan dampak progressive muscle relaxation terhadap kadar cortisol berjumlah 2 penelitian. Sebanyak 2 penelitian dilakukan terhadap mahasiswa keperawatan dan sisanya dilakukan pada mahasiswa umum.

Dampak latihan progressive muscle relaxation terhadap penurunan tingkat stress mahasiswa. Penelitian pertama dilakukan oleh Pawlow (2005) terhadap 60 orang mahasiswa (laki-laki 30 orang dan wanita 30 orang). Penelitian ini menggunakan desain RCT. Populasi dan sampel penelitian teridentifikasi dengan baik begitu juga intervensi dan outcome yang ingin dicapai. Intervensi utama adalah latihan progressive muscle relaxation tanpa intervensi pembanding, artinya hanya melihat bagaimana dampaknya jika latihan dilakukan dibandingkan jika tidak dilakukan. Randomisasi sudah dilakukan dan pada kedua kelompok seimbang dalam hal 
gender. Tetapi tidak dijelaskan tata cara randomisasi dan apakah randomisasinya blind atau tidak. Hasil penelitian menunjukkan bahwa outcome yang dicapai (penurunan tingkat persepsi stress) menurun secara bermakna setelah dilakukan latihan progressive muscle relaxation sedangkan pada kelompok kontrol tidak ada perbedaan yang bermakna. Mengingat kesamaan populasinya maka hasil penelitian ini dapat digunakan dalam pembahasan dan penelitian selanjutnya sebab latihan PMR terbukti bermanfaat, menyehatkan dan bebas biaya.

Penelitian kedua adalah penelitian yang dilakukan oleh Alexandru (2009) terhadap 3 orang mahasiswa perempuan dari Universitas Babes-Bolyai di Cluj-Napoca, yang berusia 22, 24 dan 30 tahun dan mengalami insomnia primer. Sampling dilakukan pada populasi mahasiswa yang melaporkan mengalami gangguan tidur dan berobat ke klinik kampus.

Penelitian yang dilakukan menggunakan desain case control dan mencoba menerapkan latihan progressive muscle relaxation pada populasi khusus yang memiliki gangguan tidur sebagai salah satu tanda dan gejala stress. Pemilihan subyek sudah menggunakan seleksi yang tepat dengan menyingkirkan faktor perancu (gangguan mental/psikologi, medikasi, dan insomnia sekunder), tetapi jumlah subyek masih terlalu sedikit untuk merepresentasikan populasi. Namun demikian umur subyek yang tidak jauh berbeda dengan umur mahasiswa S1 pada umumnya, maka hal ini dapat dianggap cukup representatif terhadap mahasiswa perempuan sebab seluruh sampel adalah perempuan. Penelitian ini tidak memiliki intervensi pembanding dan berhasil membuktikan bahwa latihan progressive muscle relaxation dapat menurunkan tingkat persepsi stress pada mahasiswa yang mengalami insomnia.

Penelitian ketiga dilakukan oleh Ghoncheh (2004) yang dilakukan pada 40 orang mahasiswa keperawatan terdiri dari 15 mahasiswa laki-laki dan 25 mahasiswa perempuan. Penelitian ketiga ini menggunakan desain RCT dan sudah melakukan randomisasi dengan baik untuk membagi dua kelompok sehingga setara dalam umur. Selain itu cara undian sudah memenuhi unsur blind sebab peneliti maupun responden sama-sama tidak tahu "siapa mendapatkan apa" dalam proses undiannya. Sampel yang digunakan juga representatif untuk mahasiswa secara umum dan jumlahnya memadai untuk dianalisis secara statistik. Hasil yang didapatkan juga memiliki kemaknaan yang tinggi dan lebih spesifik dari seluruh indikator-indikator stress yang ada. Hal lain yang menarik adalah pemilihan intervensi pembanding yaitu yoga 
streching yang sudah banyak dikenal dan diminati sebagai salah satu cara memperoleh relaksasi. Tidak efektifnya yoga di penelitian ini menurut Penulis adalah karena waktu pelaksanaannya hanya 30 menit. Sebab yoga sebagai sebuah terapi relaksasi biasanya membutuhkan waktu lama, mulai dari beberapa puluh menit hingga beberapa jam. Dampak yang dirasakan dari latihan yoga juga bergantung dari tingkat kelenturan tubuh serta kedalaman "keheningan" yang dirasakan oleh pelakunya. Waktu 30 menit tidaklah mencukupi untuk mencapai kedalaman dari keheningan yang dibutuhkan. Tetapi hal ini justru memperkuat asumsi bahwa latihan progressive muscle relaxation memang lebih efisien sebab dengan waktu lebih singkat dapat mencapai hasil yang optimal dibandingkan dengan yoga yang membutuhkan lebih banyak usaha dan lebih banyak waktu.

\section{Pembahasan}

\section{Efektifitas llatihan progressive muscle relaxation terhadap penurunan tingkat stress} mahasiswa.

Menurut Li (2011), Chiang (2012), Prato (2013) serta Heenan (2014) kehidupan mahasiswa penuh dengan stress. Respon stress bisa berupa anxietas, penurunan kualitas tidur, hingga ketidakmampuan melihat fenomena secara benar sehingga berpengaruh terhadap performa akademik dan performa kerja mahasiswa. Menurut Li (2011) stress tersebut bersumber dari kurangnya pengetahuan dan keterampilan terkait kompetensi yang harus dikuasai, tetapi Takasu et.al. (2012) mengemukakan bahwa stress yang terjadi pada mahasiswa lebih dikarenakan perubahan gaya hidup dan kebiasaan, seperti jadwal tidur dan bangun yang terlambat, harus terjaga semalaman saat akhir pekan atau saat libur panjang sehingga irama sirkadia berubah.

Roger \& Keller (2009) mengutip dari Roy mengemukakan bahwa manusia memiliki sistem adaptasi terhadap berbagai stimulus yang masuk. Perubahan gaya hidup mahasiswa merupakan stimulus fokal yang akan direspon secara psiko-fisiologis. Tetapi tidak semua stimulus akan berhasil direspon dengan baik (adaptif) oleh mahasiswa, hal ini bergantung dari karakteristik masing-masing mahasiswa. Salah satu bentuk respon adaptasi yang tidak efektif adalah stress (termasuk persepsi/rasa stress). Tidak efektifnya respon adaptasi tadi sebenarnya 
bukan hanya disebabkan oleh kapasitas individu saja, tetapi juga dipengaruhi oleh intensitas dan kekerapan paparan stimulus tadi.

Fatima (2014) lebih jauh menerangkan bahwa paparan stimulus yang terlalu banyak membuat tubuh "bingung" akan merespon yang mana. Karena itulah tubuh butuh untuk kembali di reset agar memperoleh ketenangan dan kembali ke "titik nol". Salah satu cara yang dapat ditempuh adalah melakukan relaksasi (dengan latihan progressive muscle relaxation). Ketika tubuh merasakan rileks maka pikiran akan menjadi tenang dan kerja persyarafan menjadi fokus. Hal inilah yang akan membantu tubuh mengembangkan kemampuan adaptasi yang adaptif terhadap stimulus-stimulus tadi.

Penelitian yang Penulis dapatkan dan lakukan telaahan dalam systematic review ini dilakukan Ghoncheh (2004), Pawlow (2005) serta Alexandru et.al (2009) dan seluruhnya menggunakan teknik PMR yang dilakukan selama 30 menit dalam satu sesi. Onset latihan ini menurut Boyd (2014) merupakan onset standar untuk memberikan kesempatan pada jantung dan sirkulasi untuk memompa dan menyalurkan lebih banyak oksigen ke organ di seluruh tubuh secara terfokus. Latihan progressive muscle relaxation yang berisi gabungan latihan stretching dan relaksasi dari kelompok otot-otot besar di tubuh manusia dari kepala sampai kaki secara teratur, termasuk latihan ringan sehingga jika dilaksanakan selama 30 menit tidak akan menimbulkan kelelahan.

Latihan progressive muscle relaxation secara rutin, yang dilakukan 1 kali sehari dan dilaksanakan terus menerus selama 1 minggu ternyata mampu membuat efek relaksasi terhadap penurunan stress tadi bertahan bahkan sampai 1 bulan sesudah latihan terakhir seperti yang sudah dibuktikan oleh Alexandru et.al (2009). Situasi ini melalui serangkaian pathway kemudian menimbulkan respon tubuh yang bermacam-macam dan oleh individu pengalaman ini akan disimpan dalam memori jangka panjang serta akan mempengaruhi individu untuk memilih reaksi/respon seperti apa yang harus terjadi jika berhadapan dengan stimulus yang identik. Dengan demikian melakukan relaksasi dapat mengurangi rasa stres yang dialami dan melatih tubuh untuk tetap rileks saat paparan stmulus terjadi berulang. Bahkan McCallie (2006) mengungkapkan relaksasi juga dapat dikatakan sebagai suatu proses 
yang dapat menyengarkan dan mengembalikan rasa semangat melalui counter conditioning dan pelepasan.

Latihan progressive muscle relaxation bahkan dilaporkan lebih efektif daripada Yoga Streching dalam meningkatkan pelepasan dan membangkitkan rasa senang seperti dilaporkan dalam penelitian ketiga. Ghoncheh (2004) telah membuktikan bahwa progressive muscle relaxation lebih baik dibandingkan dengan yoga dalam meningkatkan pelepasan stress dan meningkatkan rasa rileks, meskipun hanya dilakukan 1 kali dalam seminggu selama 4 minggu. Dan jika dilakukan sampai 5 minggu, progressive muscle relaxation juga lebih baik dalam membangkitkan rasa bahagia dan menenangkan fungsi mental dibandingkan yoga streching. Hal ini kemungkinan besar berhubungan dengan adanya peningkatan asupan oksigen akibat bernapas dalam yang tidak dilakukan pada latihan yoga streching. Meskipun keduanya sama-sama mampu mereduksi stress namun efek bahagia dan ketenangan lebih tinggi pada latihan PMR.

Schröder (2013) mengemukakan bahwa peregangan otot pada latihan progressive muscle relaxation meningkatkan kebutuhan oksigen di tingkat sel pada otot-otot besar secara simultan. Sedangkan bernapas dalam yang dilakukan di sela-sela latihan meningkatkan suplai oksigen lebih dari yang seharusnya dikompensasi oleh tubuh. Peningkatan oksigenasi dan distribusinya yang lancar akibat peningkatan kerja jantung saat peregangan menyebabkan otak dipenuhi oksigen sehinggga menurunkan metabolisme basal dan kinerja organ mengalami perlambatan, persis ketika seseorang sedang tidur. Hal inilah yang membantu meningkatkan pelepasan stress dan pencapaian relaksasi yang lebih baik.

Apabila dilakukan perbandingan terhadap hasil analisis statistik, penelitian Alexandru et.al. (2009) adalah yang terbaik dalam pembuktian manfaat progressive muscle relaxation. Penelitian ini menunjukkan bahwa kemungkinan adanya terjadinya hasil pemeriksaan prepost test yang sama hanya sebesar $0,1 \%(\mathrm{p}=0,001)$, kemungkinan hasil pemeriksaan post test yang sama dengan dengan follow-up 1 bulan hanya sebesar 0,6\% $(\mathrm{p}=0,006)$ dan kemungkinan hasil pemeriksaan follow up sama dengan hasil pre test hanya sebesar $0,1 \%$ (p $=0,001)$. Namun sayangnya jumlah evidence yang mendukung maupun membantah hal ini tidak Penulis dapatkan dalam penelusuran literatur. Meskipun minimnya literatur sejenis membuat evidence tentang dampak progressive muscle relaxation terhadap penurunan stress pada mahasiswa masih lemah tetapi hal ini justru memperkuat analisis Penulis bahwa hal ini 
membutuhkan penelitian-penelitian lebih lanjut untuk memperkaya hasil penelitian yang sudah ada. Dalam sistematic review ini Penelitian Pawlow memiliki nilai p yang tidak disebutkan sehingga diabaikan dalam pembahasan hasil statistiknya.

\section{Efektifitas latihan progressive muscle relaxation terhadap penurunan tingkat kecemasan mahasiswa.}

Heenan (2014) mengemukakan bahwa anxietas (kecemasan) merupakan salah satu manifestasi stress dan merupakan bagian dari kehidupan yang tidak terhindarkan. Cemas dicetuskan oleh rasa khawatir yang disertai dengan gejala somatic yang menandakan suatu kegiatan berlebihan dari susunan saraf otonom.

Penelitian utama terkait kecemasan dalam systematic review ini adalah penelitian Pawlow (2005) yang menunjukkan bahwa latihan progressive muscle relaxation selama 30 menit mampu menurunkan tingkat kecemasan secara bermakna, dan penelitian Prato (2013) yang membuktikan bahwa latihan progressive muscle relaxation selama 15 menit tidak berdampak pada penurunan tingkat kecemasan. Penelitian pertama yang melakukan sesi latihan PMR selama 30 menit sesuai dengan seharusnya latihan ini dilakukan sedangkan pada penelitian kedua terbukti tidak efektif kalau hanya dilakukan selama 15 menit.

Namun perlu juga menjadi pertimbangan bahwa tidak efektifnya latihan progressive muscle relaxation dalam penelitian Prato (2013) kemungkinan juga bisa disebabkan oleh desain penelitiannya. Sebab penelitian ini hanya berupaya membandingkan rerata skor kecemasan pre-post test secara keseluruhan. Sekelompok sampel diukur tingkat kecemasannya kemudian dirata-rata lalu diberikan 3 jenis perlakuan pada masing-masing anggota sampel yang dipilih secara acak. Kemudian diukur lagi skor kecemasan secara keseluruhan dan dirata-rata. Hasil rerata inilah yang kemudian dianalisis secara statistik. Seandainya desain penelitian memisahkan pengukuran pada masing-masing kelompok lalu membandingkan rerata selisih pengukuran pre-post test dari ketiga kelompok perlakuan maka menurut Penulis ada kemungkinan didapatkan hasil yang berbeda.

Artikel pendukung dari hasil penelitian Heenan (2014) melaporkan bahwa kombinasi treadmill selama 10 menit disusul PMR selama 15 menit yang dilakukan pada mahasiswa under-graduate dapat menurunkan bias pengamatan dalam persepsi gerak biologis setelah 
mengalami penurunan kecemasan. Tetapi dalam penelitian pendukung ini dilakukan penggabungan treadmill dan progressive muscle relaxation sehingga tidak dapat ditentukan outcome yang didapatkan tersebut disebabkan oleh pengaruh treadmill ataukah karena progressive muscle relaxation, sebab keduanya sama-sama memiliki andil untuk meningkatkan sirkulasi dan oksigenasi. Namun demikian penelitian ini setidaknya layak untuk membuat Penulis mempertimbangkan kembali kemungkinan efektifitas latihan progressive muscle relaxation selama 15 menit yang dikombinasi dengan treadmill dalam menurunkan kecemasan. Sepanjang penelusuran Penulis tidak ada penelitian lain yang menggunakan latihan progressive muscle relaxation tunggal hanya 15 menit untuk menurunkan skor kecemasan.

Penelitian penunjang lainnya yang dilakukan oleh Cheung (2011) yang memberikan sesi latihan progressive muscle relaxation selama 20 menit pada pasien yang mengalami pembedahan abdomen melaporkan terjadinya peningkatan kualitas hidup pasien dan mengurangi kecemasan mereka. Tetapi konteks penelitian penunjang ini tidak relevan jika diterapkan pada mahasiswa sebab faktor etiologi cemas pada mahasiswa adalah perubahan pola dan gaya hidup yang tidak pasti kapan akan menemukan keseimbangan sedangkan pada kasus-kasus bedah, kecemasan biasanya berhubungan dengan penyakit, ketidakpastian jadwal bedah dan tindakan bedah itu sendiri. Sesudah dilakukan pembedahan maka sumber-sumber kecemasan akan berkurang. Berbeda halnya dengan kehidupan mahasiswa yang di seluruh semester berhadapan dengan tugas, ujian dan kemungkinan tidak lulus.

\section{Dampak latihan progressive muscle relaxation terhadap penurunan kadar cortisol pada mahasiswa.}

Aksis Hipotalamus - Pituitari - Adrenal (HPA) adalah respon utama yang dibangkitkan ketika tubuh berhadapan dengan stress fisik maupun mental (Takasu et.al, 2012) dan bertanggung jawab terhadap sekresi hormon stress cortisol (Suresh et.al, 2012). Stress yang dialami mahasiswa menyebabkan perubahan irama sirkadia dan keluhan-keluhan fisik. Stimulus-stimulus yang berasal dari luar dan dari dalam individu berupa lingkungan perkuliahan menimbulkan reaksi-reaksi tubuh baik secara neural maupun secara kimiawi. Hal ini menstimulasi sistem saraf pusat untuk melahirkan respon psiko-fisiologis (Roys, 1991 dalam Rogers-Keller, 2009) dan salah satu penanda terjadinya respon fisiologis adalah keluarnya hormon cortisol. 
Pawlow (2005) berhasil menunjukkan dampak latihan progressive muscle relaxation terhadap penurunan kadar cortisol pada air liur. Demikian juga Krajewski et.al (2011) dapat membuktikannya pula. Tetapi terdapat perbedaan bentuk perlakuan antara keduanya. Penelitian pertama menggunakan sesi latihan progressive muscle relaxation sesuai dengan metode yang standar (dilakukan selama 30 menit) sedangkan penelitian kedua melakukan modifikasi yaitu latihan dilaksanakan hanya selama 20 menit tetapi dilakukan pada ruangan tertutup dan dengan privasi yang terjaga. Responden melakukan latihan progressive muscle relaxation dengan mendengarkan instruksi dalam sebuah bilik tertutup. Selain meningkatkan relaksasi dan oksigenasi, modifikasi lingkungan yang dibuat juga mampu mengurangi stimulus-stumulus eksternal. Selain itu, pada penelitian kedua ini pemeriksaan cortisol dilakukan 2 kali, yaitu pada siang hari saat waktu istirahat makan siang (sesudah beraktifitas) dan pada pagi hari (sesudah tidur).

Krajewski et. al. (2011) melakukan pengandalian stimulus eksternal dengan 2 cara, yaitu small talk dan ruangan privasi. Penelitian ini membuktikan bahwa small talk tidak memiliki makna yang berarti dalam menurunkan hormon stress. Tetapi jika pengendalian stimululs eksternal itu digabungkan dengan latihan progressive muscle relaxation maka penurunan cortisol lebih bermakna ketika tubuh dalam puncak kelelahan. Berbeda halnya dengan saat bangun tidur, tubuh kita sudah beristirahat dan belum mengalami stress maka tidak ada perbedaan kadar cortisol yang bermakna. Artinya pada saat bangun tidur, semua stressor sudah berhasil dinetralkan sehingga level hormon stress tidak banyak berubah. Latihan PMR hanya bermakna ketika tubuh dalam keadaan lelah dan butuh relaksasi.

\section{Simpulan}

Berdasarkan hasil dan pembahasan yang telah Penulis sampaikan, maka ada beberapa hal yang dapat dijadikan kesimpulan, yaitu : Pelaksanaan latihan progressive muscle relaxation dalam menurunkan tingkat stress mahasiswa harus dilakukan dengan durasi 30 menit per sesi untuk mendapatkan hasil yang maksimal. Efek latihan progressive muscle relaxation dalam menurunkan stress yang dilaksanakan secara rutin minimal 1 hari selama 1 minggu masih dapat dirasakan bahkan hingga 1 bulan setelah latihan terakhir. Latihan progressive muscle relaxation bahkan lebih baik dari yoga streching (hatha) untuk mencapai disengagement dan physical relaxation jika dilakukan minimal 1 hari dalam seminggu selama 4 minggu serta mencapai joy dan mental quiet yang lebih baik pula jika diteruskan sampai minggu kelima. 
Pelaksanaan latihan progressive muscle relaxation dalam menurunkan tingkat kecemasan mahasiswa idealnya juga dilaksanakan dengan durasi 30 menit dalam satu sesi. Sesi latihan dengan durasi kurang dari itu kurang bermakna dalam menurunkan tingkat kecemasan mahasiswa. Pelaksanaan latihan progressive muscle relaxation dalam menurunkan kadar cortisol pada mahasiswa juga harus dilakukan dengan 1 sesi penuh (30 menit). Hasil yang lebih baik akan diperoleh apabila dilakukan modifikasi lingkungan untuk membatasi stimulus eksternal selama sesi latihan berlangsung. Dampak dari pengendalian ini bisa mencapai tingkat relaksasi mendekati hasil yang dicapai dengan tidur.

\section{DAFTAR PUSTAKA}

Alexandru, B.V., Robert, V., Viorel, L., Vasile, B. (2009) Treating Primary Insomnia: A Comparative Study of Self-Help Methods and Progressive Muscle Relaxation. Journal of Cognitive and Behavioral Psychotherapies, Vol. 9, No. 1, March 2009, 67-82.

Boyd, C. (2014) Study Skills for Nurses Student. Survival Skills Series : Survive your nursing course with these essential guides for all student nurses. West Sussex : John Wiley \& Sons, Ltd

Chiang,Y.C., Arendt, S.W., Zheng, T., Hanisch, K.A. (2012) The Effects of Sleep on Academic Performance and Job Performance. College Student Journal.

Cheung, Y. L., Molassiotis, A., \& Chiang, A. M. (2011). A pilot study on the effect of progressive muscle relaxation training of patients after stoma surgery. European Journal Of Cancer Care, 10(2), 107-114.

Clark, C. M., Nguyen, D. T., \& Barbosa-Leiker, C. (2014). Student Perceptions of Stress, Coping, Relationships, and Academic Civility.

Dayapoğlu, N., \& Tan, M. (2012). Evaluation of the effect of progressive relaxation exercises on fatigue and sleep quality in patients with multiple sclerosis. Journal Of Alternative And Complementary Medicine (New York, N.Y.), 18(10), 983-987. doi:10.1089/acm.2011.0390

Dehdari, T., Heidarnia, A., Ramezankhani, A., Sadeghian, S., \& Ghofranipour, F. (2009). Effects of progressive muscular relaxation training on quality of life in anxious patients after coronary artery bypass graft surgery. The Indian Journal Of Medical Research, 129(5), 603-608

Demiralp, M., Oflaz, F., \& Komurcu, S. (2010). Effects of relaxation training on sleep quality and fatigue in patients with breast cancer undergoing adjuvant chemotherapy. Journal of Clinical Nursing, 19(7-8), 1073-1083. doi:10.1111/j.1365-2702.2009.03037.x

Fatima, H. (2014). An extensive mixed-methods analysis: mindfulness meditation, attentional abilities, perceived stress and emotional acceptance.

Feldman, D. D. (2012). Can Hope be Changed in 90 Minutes? Testing the Efficacy of a Single-Session Goal-Pursuit Intervention for College Students. Journal Of Happiness Studies, 13(4), 745-759.

Gaultney, J.F. (2010) The Prevalence of Sleep Disorders in College Students: Impact on Academic Performance. Journal of American College Health, Vol. 59, No. 2 
Ghafari, S., Fazlolah A., Nabavi, M., Anoshirvan, K., Memarian, R., and Rafatbakhsh, M. (2009). "Effectiveness of applying progressive muscle relaxation technique on quality of life of patients with multiple sclerosis." Journal Of Clinical Nursing 18, no. 15: 21712179. MEDLINE with Full Text, EBSCOhost (accessed November 22, 2014)

Ghoncheh, S., Smith, J.C. (2004) Progressive Muscle Relaxation, Yoga Stretching, and ABC Relaxation Theory. Journal of Clinical Psychology, Vol. 60(1), 131-136. Published online in Wiley InterScience (www.interscience.wiley.com). DOI: 10.1002/jclp.10194

Heenan, A., \& Troje, N. F. (2014). Both physical exercise and progressive muscle relaxation reduce the facing-the-viewer bias in biological motion perception.Plos One, 9(7), e99902. doi:10.1371/journal.pone.0099902

Krajewski, J. R. (2011). Relaxation-induced cortisol changes within lunch breaks - an experimental longitudinal worksite field study. Journal Of Occupational \& Organizational Psychology, 84(2), 382-394.

Lauche R; Materdey S; Cramer H; Haller H; Stange R; Dobos G; Rampp T, (2013) Effectiveness of Home-Based Cupping Massage Compared to Progressive Muscle Relaxation in Patientswith Chronic Neck Pain-A Randomized Controlled Trial. Plos One [PLoS One], ISSN: 1932-6203, 2013 Jun 07; Vol. 8 (6), pp. e65378; Publisher: Public Library of Science; PMID: 23762355

Li, H. C., Wang, L. S., Lin, R. H., Lee, I. (2011) The effect of a peer-mentoring strategy on student nurse stress reduction in clinical practice. International Nursing Review 58, 203 210

McCallie, M.S., Bloom, C.M., Hood, C.J. (2006) Progressive Muscle Relaxation. Journal of Human Behavior in the Social Environment, Vol. 13(3) 2006. doi:10.1300/J137v13n03_04

Pawlow, L. A., \& Jones, G. E. (2005). The impact of abbreviated progressive muscle relaxation on salivary cortisol and salivary immunoglobulin A (sIgA). Applied Psychophysiology And Biofeedback, 30(4), 375-387.

Prato, C.A. \& Yucha, C.B. (2013) Biofeedback-Assisted Relaxation Training to Decrease Test Anxiety in Nursing Students. Nursing Education Perspective. March/April 2013. Vol.34., No.2.

Rasid, Z. S. (1998). The effects of two types of relaxation training on students' levels of anxiety. Adolescence, 33(129), 99.

Roger, C. \& Keller, C. (2009) Roy's Adaptation Model To Promote Physical Activity Among Sedentary Older Adults. Geriatr Nurs. 2009;30 (2 Suppl) : 21-26. doi:10.1016/j.gerinurse.2009.02.002

Schröder, A. R., Heider, J., Zaby, A., Gollner, R. (2013). Cognitive Behavioral Therapy Versus Progressive Muscle Relaxation Training for Multiple Somatoform Symptoms: Results of a Randomized Controlled Trial. Cognitive Therapy \& Research, 37(2), 296306.

Singh, V. P., Rao, V., V, P., R C, S., \& K, K. P. (2009). Comparison of the effectiveness of music and progressive muscle relaxation for anxiety in COPD--A randomized controlled pilot study. Chronic Respiratory Disease, 6(4), 209-216. doi:10.1177/1479972309346754

Suresh, P., Matthews, A., Coyne, I. (2012) Stress and stressors in the clinical environment: a comparative study of fourth-year student nurses and newly qualified general nurses in Ireland. Journal of Clinical Nursing, 22, 770-779, doi: 10.1111/j.13652702.2012.04145.x

Takasu, N.N., Takenaka, Y., Fujiwara, M., and Toichi, M. (2012) Effects of regularizing sleep-wake schedules on daytime autonomic functions and psychological states in

Jurnal SMART Keperawatan Sekolah Tinggi Ilmu Kesehatan (STIKes) Karya Husada Semarang 
healthy university students with irregular sleep-wake habits. Sleep and Biological Rhythms. 2012; 10: 84-93 doi:10.1111/j.1479-8425.2011.00524.x

Washington, G. T. (2009). Effects of Anxiety Reducing Interventions on Performance Anxiety in Graduate Nurses.

Zhou, K., Li, X., Li, J., Liu, M., Dang, S., Wang, D., \& Xin, X. (2014). A clinical randomized controlled trial of music therapy and progressive muscle relaxation training in female breast cancer patients after radical mastectomy: Results on depression, anxiety and length of hospital stay. European Journal Of Oncology Nursing: The Official Journal Of European Oncology Nursing Society, [Eur J Oncol Nurs], ISSN: 1532-2122, 2014 Aug 30; Publisher: Churchill Livingstone; PMID: 25181938 